\title{
Measuring Master Students' Online Learning Perceptions and Satisfaction during Covid-19 Crisis in Morocco
}

\author{
Abdelmajid JAMIAI \\ Hassan First University-Morocco \\ abdelmajid.jamiai@uhp.ac.ma
}

DOI: http://doi.org/ 10.36892/ijlls.v3i1.488

\begin{tabular}{ll} 
Received: & Abstract \\
05/01/2021 & The implementation of technology in higher education is highly considered in \\
& research conducting during Covid-19 crisis in Morocco. This article examines \\
Accepted: & students' perceptions and the degree of satisfaction in online classes for one \\
25/02/2021 & femester during the emergency of Covid-19 pandemic. The research design \\
& from thirty-two (32) respondents who are enrolled in two Master Programs of \\
\hline Keywords: & 'Applied Language Studies and Research in Higher Education' and \\
Covid-19, & Language, Communication, and Society' at the Faculty of Letters and Human \\
online education, & Sciences of Dhar Mehraz of Sidi Mohamed Ben Abdellah University in \\
quality of higher & Morocco as a convenient sampling. The SPSS (Statistical Package for Social \\
education, & Sciences) was used to analyze the retrieved data via e-mails. The findings of \\
perceptions. & this study demonstrate that the majority of Master students would like to \\
& resort to hybrid education instead of online classes per se. They also show \\
& that online learning satisfaction does not receive high levels of agreement \\
among the respondents. The paper ends up with some recommendations for \\
the implementation of online education in higher education.
\end{tabular}

\section{INTRODUCTION}

Starting from the fact that Covid-19 crisis broke out in the beginning of 2020, educational policies took different streams to cope with that unexpected gloomy situation. Education in the entire world has been put in a critical position, characterized in the ways to afford education for all and in the quick and effective method (s) to achieve learning objectives and satisfaction. The first reaction to such circumstances was to adopt online education as the only alternative for the physical classroom. Stakeholders in Moroccan higher education decided on the implementation of two types of education: distance and online. Distance education is embodied in integrating TV channels and radio for university students who cannot be connected to the network and who live in rural areas. The second type of education that was implemented is online learning by integrating institutional platforms and other learning applications. Between these two different types, there emerged many voices, especially among university professors and their learners, which either approved or disapproved of these new ways of teaching/learning. In this framework, the study tries to examine if the new pedagogy is appropriate for students and their learning and to see if students consider online classes as a real substitute for face-to-face instruction.

\section{LITERATURE REVIEW}

The growth of e-learning in the arena of education in general and during the pandemic of Covid-19, in particular, in Morocco has become in the center of academia and the public opinion. The debate about the effectiveness and the quality of online learning is also controversial in the sense that researchers' views diverge at the levels of validity and 
credibility of the unexpected new pedagogy adopted in Moroccan higher education. The complexities in the teaching process never cease to raise hindrances to university professors and students. One of these is the mode of instruction delivery. Practitioners in the field of education shift their face-to-face philosophy of instruction to the online pedagogy by looking for swift ways to adopt the course content, methods and students' needs to make them effective online. Within such circumstances, professors and students have made up their minds to meet virtually via the use of networked computers, educational platforms and digital applications longing for the academic continuity as a preventive measure against the proliferation of the virus.

\subsection{Definition of e-learning}

Across the readings in the literature, e-learning is defined from multiple perspectives. First, e-learning is seen from the instructor angle; second, monitoring e-learning necessitates the integration of the machine, notably the computer; and third, the enhanced content determines the relationship between the professor and the students as active members from one side and the course content from the other side. In the same vein, the most pertinent definition that suits these perspectives is the one proposed by Cohen (1999) who states that elearning is the act of "finding the best match between the needs of a given set of learners with their individual learning demands to learn a given content, using a given set of learning tools" (Cited in Cohen, 2007, p. 12). This would imply that e-learning starts with the needed technological devices set for learners to satisfy their needs in accordance with what they are given to learn. Moreover, online learning provides opportunities for learners to set their own goals via the educational technologies established by the organization and the institution they belong to. More definitions are suggested, beginning with Hicks (2004) who claims that elearning has been defined by the American Society for Training and Development as "anything delivered, enabled, or mediated by electronic technology for the explicit purpose of learning". Moreover, Imel (2002) defines e-learning as "instruction and learning experiences that are delivered via electronic technology such as the Internet, audio, videotape, satellite broadcast, interactive TV, and CD-ROM" (p. 3). Another definition of e-learning by Jackson (2001) views it from two subdivisions of "technology-delivered e-learning" and "technology enhanced e-learning". The first subdivision of technology delivered e-learning is where the learner is "never in physical close proximity to the instructor and may be delivered via a blend of asynchronous and synchronous technologies" (p. 316). As a second subdivision, technology enhanced e-learning is where the learner "has the opportunity to meet face-to-face with the instructor is a supplement to traditional, on-campus learning" (Jackson, 2001, p. 316, cited in Partridge and Edwards, 2005, p. 12).

The definitions of e-learning above pour in the same scope that is teaching learners via multiple electronic tools to develop their experiences. Online learning, in this sense, focuses on the mode of delivering a course to overcome the boundaries of the physical presence and to reach the psychological proximity. Additionally, e-learning complements traditional instruction by means of affording learners the chance to meet synchronously online but online learning outdoes the traditional mode for being asynchronous or flexible in time. Therefore, the integration of information communication technologies as digital mediators can boost e-learning by enabling learners to interact, share and collaborate.

\subsection{The role of the teacher in e-learning}

Starting from the fact that the teacher has different roles to play in face-to-face instruction and in accordance with the adopted method of teaching, an e-teacher's role has taken different new emerging forms. Cohen and Nycs (2006) state that: 
The role of the teacher in e-Learning is not limited to being the presenter of knowledge. E-Learning requires more from teachers than lectures. Certainly ICT (Information and Communication Technologies) can be used for "traditional" teaching; it also can be useful for e-Learning. It enables teachers to package learning opportunities in an increasing number of alternative ways so as best to meet the varying needs of different students (p. 5).

This means that the availability of media tools makes it convenient to university professors to vary the content they intend to share with learners. In this respect, online learning revolutionizes the teacher's roles by deconstructing the canon of the face-to-face classroom. The teacher's role now is referred to as a reference for learners at the knowledgeable and technical levels, meaning that the teacher in higher education is expected to be equipped with all that is needed for learners. In brief, university professors' main role is to vary the methods and approaches they implement as the media tools vary. Partridge and Edwards (2005) state that "Ideally, beyond the "lecture", the instructor should package, sequence, and deliver the knowledge, skills, and abilities being learned in response to each learner's unique needs" (p.4). To differently put, university professors are found in situations where they arrange online courses in one package, including the skills with which learners need to respond to e-learning classes. Moreover, the teacher's job in e-Learning is to assist the learning procedure and to monitor the advancement in learning (Bielecki, 2002; Razak, Yassin, \& Maasum, 2020).

\subsection{The role of the student in e-learning}

Since the students are partners in the teaching/learning process, their roles in elearning are not socially supported but digitally done. It is obvious that the role of the student in face-to-face instruction is maintained by the presence of the teacher and the other classmates in the physical classroom. However, e-learning is characterized by the psychological presence of the human side in the virtual learning community. According to Cohen and Nycs (2006), "Using an e-learning system enables a student to be active in building knowledge" within the four ensuing supportive formulas:

1- common learning within the team;

2- interactive process of group building of knowledge;

3- active participation in generating and selecting information;

4- constructing knowledge in the context of other students' points of view (p.7).

In the first principle, students do not need to physically meet each other in face-toface classroom but online meetings are arranged. In the second principle, during online classes, the flexibility of the medium makes it possible for students to have access to the online discussion so that their peers can react upon. In the third principle, by being present online, students' active participation democratizes learning by raising topics that match with everyone's curiosity. In the fourth principle, the students' sense of belonging to the group creates equality among students who can be open to different meanings and interpretations within the discussion group. This quality serves them to build their own knowledge through their critical thinking skill. In a nutshell, the student's role in e-learning is embodied in the dynamism in knowledge construction and modeling without ignoring the teacher's mission to facilitate and monitor their learning development. Thus, the table below summarizes the models adopted in each type of education.

\begin{tabular}{|c|c|c|}
\hline $\begin{array}{c}\text { Model } \\
\text { Feature }\end{array}$ & $\begin{array}{c}\text { Traditional } \\
\text { education model }\end{array}$ & $\begin{array}{c}\text { Distance education system } \\
\text { (e-Learning) }\end{array}$ \\
\hline
\end{tabular}




\begin{tabular}{|c|c|c|}
\hline $\begin{array}{c}\text { Principle } \\
\text { Knowledge sources }\end{array}$ & Teacher & $\begin{array}{l}\text { knowledge bases in education } \\
\text { system, any knowledge source } \\
\text { accessed physically or electronically }\end{array}$ \\
\hline $\begin{array}{c}\text { Additional } \\
\text { Knowledge Source }\end{array}$ & $\begin{array}{c}\text { books, manuals, } \\
\text { audio and video } \\
\text { materials }\end{array}$ & traditional sources, teacher \\
\hline Assessment & only by teacher & $\begin{array}{l}\text { System and teacher who is } \\
\text { responsible for final assessment }\end{array}$ \\
\hline Quality of education & $\begin{array}{l}\text { dependents on } \\
\text { teachers' quality, } \\
\text { degree of } \\
\text { knowledge, and } \\
\text { ability to teach that } \\
\text { knowledge }\end{array}$ & $\begin{array}{l}\text { depends on electronic knowledge } \\
\text { sources quality, other didactic } \\
\text { materials, and the teaching style } \\
\text { (such as collaborative learning) }\end{array}$ \\
\hline
\end{tabular}

Types of Education Models, adopted from Nicole A. Buzzetto-More (Ed.). (2006, p. 6).

\section{RATIONALE AND PURPOSE}

The main purpose of this quantitative study is to draw a demarcation line between face-to-face instruction and online learning. To address the existing gap in the few conducted studies on online learning in higher education in Morocco, the present study aims at reinforcing research in terms of implementing technology in education and examining the extent to which Moroccan EFL (English as a Foreign Language) learners, particularly Master students, are satisfied with the quality of online education as a substitute to face-to-face classrooms during Covid-19 pandemic.

\section{RESEARCH QUESTIONS}

To examine the effectiveness of online learning with the concentration on students' perceptions and their degree of satisfaction during Covid-19 pandemic throughout one semester in higher education in Morocco, and the extent to which Master students learn better in online classes, two main research questions were set to achieve the objectives of the present study:

1- Does online learning satisfy the learning needs of Master students in Morocco during the crisis of Covid-19?

2- To what extent do Master students improve their online learning experience during Covid-19?

\section{METHODOLOGY}

A quantitative research design was used to measure the relationship between students' perception and satisfaction as dependent variables and online learning during Covid-19 as an independent variable. In this study, a questionnaire was used to collect data on students' perceptions towards online learning and their satisfaction. The questionnaire was addressed to thirty-two respondents. The participants in this study were those enrolled in two Master Programs of 'Applied Language Studies and Research in Higher Education' and 'Language, Communication, and Society' at the Faculty of Letters and Human Sciences of Dhar Mehraz at the University of Sidi Mohamed Ben Abdellah, Fes. The choice of the sample is based on the convenient sampling procedure since the researcher delivered a presentation as a guest speaker on one of the issues set to achieve the course objectives in topics related to applied linguistics. This gave him an easy access to the members of the Master community who did not hesitate to reply to the questionnaires. Furthermore, the respondents are those students 
who were pre-selected to sit for the interview on the criterion of their distinguished grades. Then, they were accepted to enrol in the Master Program for the competencies they demonstrated at the linguistic and communicative levels. For data analysis, the SPSS (Statistical Package for Social Sciences) was used to analyse the elicited data. The questionnaire was divided into four clusters in which questions addressing one of the issues were aggregated. The questionnaire comprises 'yes-no' questions, options to tick and the Likert-scale.

\section{RESULTS}

\section{ReliabilityStatistics}

\begin{tabular}{ccc}
\hline Cronbach's & Cronbach's Alpha Based on & N of Items \\
Alpha & Standardized Items & \\
$\mathbf{. 7 3 3}$ & $\mathbf{. 7 5 2}$ & $\mathbf{1 5}$ \\
\hline
\end{tabular}

To test the internal consistency of the questionnaire used to conduct this study, Cronbach's Alpha Based on Standardized Items was used. The results show that the items of the questionnaire are reliable at $\mathbf{. 7 5 2}$, meaning that the analysis of the different scales used for the questionnaire items is reliable. So, the measurement of the internal consistency shows that the set of items are closely related as a group. In brief, $\boldsymbol{\alpha}=\mathbf{. 7 5 2}$ indicates an acceptable level of reliability (Hulin, Netemeyer, and Cudeck, 2001).

\section{Age, Gender and Geographical Location}

The age of the respondents arranges from 21 to 42. For the gender frequency distribution, $\mathbf{6 5 . 6 3} \%$ represents the female respondents and $\mathbf{3 4 . 3 8} \%$ represents the male respondents who took part in this study.The respondents are geographically distributed among the urban areas which represent $\mathbf{7 1 . 8 8} \%$ while $\mathbf{2 8 . 1 3} \%$ represents those whose location is in the rural areas.

Modes of Delivery Preference

\begin{tabular}{llrrrr}
\hline & Frequency & Percen & \multicolumn{2}{c}{ Valid } & \multicolumn{2}{c}{$\begin{array}{c}\text { Cumulative } \\
\text { Percent }\end{array}$} \\
Valid & Face-to-face & 14 & 43.8 & 43.8 & 43.8 \\
& courses & & & & \\
& Hybrid courses & 18 & 56.3 & 56.3 & 100.0 \\
Online courses & 0 & 0 & 0 & 0 \\
\hline & 32 & 100.0 & 100.0 & \\
\hline
\end{tabular}

The item which addresses the respondents' preference to study includes three options: Face-to-face courses, Online Courses and Hybrid classes. The results show that $\mathbf{5 6 . 2 5 \%}$ opted for "hybrid course" and $\mathbf{4 3 . 7 5 \%}$ chose "face-to-face courses". But no one of the respondents selected only the "online courses" option.

The modality used for online delivery

\begin{tabular}{|c|c|c|c|c|c|}
\hline \multirow{4}{*}{ Valid } & & Frequency & Percent & Valid Percent & Cumulative Percent \\
\hline & Synchronous & 8 & 25.0 & 25.0 & 25.0 \\
\hline & Both & 24 & 75.0 & 75.0 & 100.0 \\
\hline & $\begin{array}{l}\text { Asynchrono } \\
\text { us }\end{array}$ & 0 & 0 & 0 & 0 \\
\hline
\end{tabular}




\section{$\begin{array}{llll}\text { Total } & 32 & 100.0 & 100.0\end{array}$}

For this item that includes three options: "Synchronous", "asynchronous" and "both", the findings demonstrate that $\mathbf{7 5 \%}$ of the respondents use both synchronous and asynchronous modes of online course delivery, while $\mathbf{2 5} \%$ of the whole sample sees that courses should be delivered at the same time like face-to-face. However, no respondent from the whole sample declared that "asynchronous" mode of delivery is used independently.

The benefit from training on the use of platforms and applications

\begin{tabular}{llllll}
\hline \multirow{4}{*}{ Valid } & & Frequency & Percent & Valid Percent & Cumulative Percent \\
& Yes & 17 & 53.1 & 53.1 & 53.1 \\
& No & 15 & 46.9 & 46.9 & 100.0 \\
& Total & 32 & 100.0 & 100.0 & \\
\hline
\end{tabular}

For the item (7) related to benefiting from any training on platform and applications use, the findings indicate that $\mathbf{5 3 . 1 \%}$ of the respondents have had the chance to be trained either before or during the Covid-19 pandemic; while 46.9\% declared that they had never benefited from any training on how to handle and manage e-learning platforms and educational applications.

Perception frequencies on whether discussion boards (online discussion) are more comfortable than face-to-face modes of discussion

\begin{tabular}{llllll}
\hline \multirow{3}{*}{ Valid } & & Frequency & Percent & Valid Percent & Cumulative Percent \\
& Yes & 10 & 31.3 & 31.3 & 31.3 \\
& No & 22 & 68.8 & 68.8 & 100.0 \\
& Total & 32 & 100.0 & 100.0 & \\
\hline
\end{tabular}

For perceptions towards whether discussion boards (online discussion) are more comfortable than face-to-face modes of discussion, descriptive statistics illustrate that $\mathbf{3 1 . 3} \%$ of the respondents see that face-to-face discussion can be replaced by online discussion. From the other side of the coin, $\mathbf{6 8 . 8} \%$ represents those who refuse the idea that classroom interaction is replaceable by discussion boards.

Perceptions of time to think and respond towards online discussions

\begin{tabular}{llllll}
\hline \multirow{4}{*}{ Valid } & & Frequency & Percent & Valid Percent & Cumulative Percent \\
& Yes & 23 & 71.9 & 71.9 & 71.9 \\
& No & 9 & 28.1 & 28.1 & 100.0 \\
& Total & 32 & 100.0 & 100.0 & \\
\hline
\end{tabular}

Although the findings of the previous item on face-to-face discussion replacement by online discussion demonstrate that respondents are against it, their attitudes towards online discussions and the enough time they provide to think and respond show that e-learning is flexible in time with $\mathbf{7 1 . 9} \%$ and inflexible with $\mathbf{2 8 . 1} \%$.

The impact of online learning experience on the ability to communicate with the instructor throughout the semester (S2/2020 _ Spring _ of Covid-19)

\begin{tabular}{llllll}
\hline \multirow{3}{*}{ Valid } & & Frequency & Percent & Valid Percent & Cumulative Percent \\
& Yes & 12 & 37.5 & 37.5 & 37.5 \\
& No & 20 & 62.5 & 62.5 & 100.0 \\
& & & &
\end{tabular}




$100.0 \quad 100.0$

Concerning respondents' experience with online learning and its usability to make them communicate effectively with their instructor throughout semester 2, 2020 (Spring Covid-19), findings display that $\mathbf{3 7 . 5} \%$ of the sample see that their online learning experience helps them to be effective, while $\mathbf{6 2 . 5} \%$ do not benefit from the online learning to interact with their instructor (s). This means that Covid-19 affects negatively the respondents' attitudes towards instructor-student interaction.

The role of the teacher in online classes vs. face-to-face

\begin{tabular}{llllll}
\hline \multirow{4}{*}{ Valid } & & Frequency & Percent & Valid Percent & Cumulative Percent \\
& Yes & 10 & 31.3 & 31.3 & 31.3 \\
& No & 22 & 68.8 & 68.8 & 100.0 \\
& Total & 32 & 100.0 & 100.0 & \\
\hline
\end{tabular}

For the item that investigates the role of the teacher in online classes in comparison to that of face-to-face, descriptive statistics show that $\mathbf{3 1 . 3} \%$ from the whole sample see that there is no difference between the teacher's role in online classes and in face-to-face. However, $\mathbf{6 8 . 8} \%$ of the respondents declare that there is dissimilarity in the teacher's role in both spaces. Findings of this item are compatible with those of the previous item that concerns the interaction between the instructor and the student, meaning that online classes affect not only the role of the instructor but the interaction as well.

The impact of using technology on the creativityof the instructor online in comparison to face-to-face classroom

\begin{tabular}{|c|c|c|c|c|c|}
\hline \multirow{3}{*}{ Valid } & & Frequency & Percent & Valid Percent & Cumulative Percent \\
\hline & Yes & 17 & 53.1 & 53.1 & 53.1 \\
\hline & No & 15 & 46.9 & 46.9 & 100.0 \\
\hline & Total & 32 & 100.0 & 100.0 & \\
\hline
\end{tabular}

Findings of attitudes towards the idea that the use of technology makes instructors more creative in teaching than in a face-to-face classroom indicate that $\mathbf{5 3 . 1 \%}$ represents those respondents who see that digital media inspire teachers to be creative, while $\mathbf{4 6 . 9 \%}$ consider the opposite in the sense that the use of technology has no added value to online teaching. This may indicate that both online classes and face-to-face classrooms have approximate frequencies as far as creativity is concerned.

Summary of Frequencies of students' training, discussion boards and instructors' characteristics

\begin{tabular}{lll}
\hline \multicolumn{1}{c}{ Statement } & Yes (\%) & No (\%) \\
\hline $\begin{array}{l}\text { Q7 Have you benefited from any training on platform and } \\
\text { applications use? }\end{array}$ & 53.1 & 46.9 \\
$\begin{array}{l}\text { Q8 Do you see that discussion boards (online discussion) are } \\
\text { more comfortable than face-to-face modes of discussion? }\end{array}$ & 31.3 & 68.8 \\
$\begin{array}{l}\text { Q9 Do you think that online discussions provide you with } \\
\text { enough time to think and respond? }\end{array}$ & 71.9 & 28.1 \\
$\begin{array}{l}\text { Q10 Do you think that your online learning experience makes } \\
\text { you able to communicate effectively with your instructor }\end{array}$ & 37.5 & 62.5 \\
\hline
\end{tabular}


throughout this semester (S2/ 2020 _ Spring _ of Covid-19)?

Q15 Do you see that the role of the teacher in online classes is the same as in face-to-face?

Q16 Do you see that the use of technology makes instructors

31.3

68.8

more creative in teaching than in a face-to-face classroom?

Perceptions towards online experiences during Covid-19

\begin{tabular}{llllll}
\hline Statements & $\begin{array}{l}\text { Strongly } \\
\text { agree }\end{array}$ & Agree & Undecided & Disagree & $\begin{array}{l}\text { Strongly } \\
\text { disagree }\end{array}$ \\
\hline $\begin{array}{l}\text { Q11 I see that my needs as a } \\
\text { Master student are met in the } \\
\text { online learning environment? }\end{array}$ & 6.3 & 31.3 & 21.9 & 37.5 & 3.1 \\
$\begin{array}{l}\text { Q12 I see that online education is } \\
\text { enjoyable for me? }\end{array}$ & 15.6 & 34.4 & 9.4 & 34.4 & 6.3 \\
$\begin{array}{l}\text { Q13 I see that online courses are } \\
\text { better than face-to-face classes? }\end{array}$ & 3.1 & 6.3 & 6.3 & 50 & 34.4 \\
$\begin{array}{l}\text { Q14 I see that online classes can } \\
\text { replace face-to-face classes? }\end{array}$ & $0 \%$ & 9.4 & 12.5 & 43.8 & 34.4 \\
\hline
\end{tabular}

The results of the perceptions towards online experiences during Covid-19 are based on four items $(11,12,13$ and 14) and will be described on the basis of grouping scales of 'strongly agree' with 'agree' and 'disagree' with 'strongly disagree'. For the item (11) "I see that my needs as a Master student are met in the online learning environment", it was found that $\mathbf{3 7 . 6} \%$ of the whole sample expressed agreement regarding their satisfaction with online classes, while $\mathbf{4 0 . 6} \%$ expressed their disagreement. This indicates that the needs of the respondents are approximately satisfied by fifty per cent when they went online.

For attitudes towards item 12 (I see that online education is enjoyable for me), findings designate that $\mathbf{5 0} \%$ of the sample either agree or strongly agree with the fact that online education is enjoyable in contrast to $\mathbf{4 0 . 9} \%$ of the respondents who consider online education as unpleasant. This may back up findings of item 11 in which respondents' requirements are not called for in online classes $(\mathbf{4 0 . 6} \%)$.

The results of item 13 on "I see that online courses are better than face-to-face classes" show that $\mathbf{8 4 . 4 \%}$ of the respondents prefer face-to-face classrooms whereas only 9.4\% see that online classes are better than face-to-face ones. This means that Master students are still unsatisfied during the emergency of Covid-19.

Findings of item 14 "I see that online classes can replace face-to-face classes" support the results of item 13 in the sense that $\mathbf{7 8 . 2 \%}$ of the respondents see that online classes can never be a substitute for face-to-face classes. But only $\mathbf{9 . 4 \%}$ who either disagree or strongly disagree with the belief that face-to-face classes are replaceable.

To sum up, computing the findings of the four items $(11,12,13$ and 14) indicates that 26.4\% of the respondents whose perceptions of online experiences during Covid-19 are positive; while $\mathbf{6 0 . 9 7 \%}$ represent the negative attitude respondents have towards online classes, which would clearly affect their degree of satisfaction.

Students'satisfaction in the learning community during Covid-19

\begin{tabular}{llllll}
\hline Statements & $\begin{array}{l}\text { Strongly } \\
\text { agree }\end{array}$ & Agree & Undecided & Disagree & $\begin{array}{l}\text { Strongly } \\
\text { disagree }\end{array}$ \\
\hline Q17 I see that belonging to the & 15.6 & 50 & 12.5 & 15.6 & 6.3 \\
\hline
\end{tabular}




$\begin{aligned} & \text { online learning community helps } \\ & \text { me interact with other students? }\end{aligned}$
$\begin{aligned} & \text { Q18 I see that the online } \\ & \text { environment promotes sufficient } \\ & \text { sharing and caring among }\end{aligned}$
$\begin{aligned} & \text { students? } \\ & \begin{array}{l}\text { Q19 I see that the online } \\ \text { environment is a safe place }\end{array}\end{aligned}$
$\begin{aligned} & \text { where I can be confident in } \\ & \text { completing group work with } \\ & \text { other students? }\end{aligned}$

The results of the students' satisfaction in the learning community during Covid-19 are based on three items (17, 18 and 19) and will be described on the basis of grouping scales of 'strongly agree' with 'agree' and 'disagree' with 'strongly disagree'.

For the item 17 "I see that belonging to the online learning community helps me interact with other students", it was found that $\mathbf{6 6 . 6} \%$ see that the online learning environment provides respondents with an area for student-student interaction, whereas 21.9\% see the opposite in the sense that their belonging to the online community is unable to cater for online interaction.

In the same respect, findings of item 18 on "I see that the online environment promotes sufficient sharing and caring among students" would imply that $\mathbf{5 0} \%$ of the targeted sample witness that the online learning environment encourages for adequate practices among members of the community. However, 31.3\% of the respondents expressed their dissatisfaction towards what is being shared within the online learning community during Covid-19.

Descriptive statistical results of item 19 "I see that the online environment is a safe place where I can be confident in completing group work with other students" indicate that 50.1\% of the whole sample expressed their conviction about the learning security within the community, while $\mathbf{2 1 . 9 \%}$ of the respondents are anxious within the online community and incapable of performing their tasks with their peers.

To recapitulate, computing the findings of the three items (17, 18 and 19) indicates that $\mathbf{5 5 . 2 3} \%$ of the respondents were satisfied during Covid- 19, while $\mathbf{2 5 . 0 3} \%$ represents those who were unsatisfied with online classes.

\section{DISCUSSION}

In the present study, two research questions were set to scrutinize the efficiency of online learning during Covid-19 pandemic in higher education in Morocco and the extent to which Master students enhance their learning in distance education. According to the findings of the quantitative study, the respondents perceive e-learning as complementary to face-toface instruction and not as a substitute to it in the sense that the way online classes were managed did not suit their learning strategies. Moreover, though Master students were very advanced in their levels, they still need the professor's support in terms of the use of the tools, time management and interaction. Therefore, the quality of e-learning classes makes it an ineffective substitute for face-to-face instruction during Covid-19 pandemic, which determines their low degree of satisfaction. However, these students' satisfaction increases in terms of belonging to the learning community, which helps them share knowledge and raise issues related to their field of study. In the same respect, online learning classes create a comfortable environment for students to fulfil their tasks, promoting care and selfconfidence. In brief, the findings of the study reveal that there is interaction between Master students with their peers and professors but online learning hinders interaction between students and the course content they are supposed to know, which strongly confirms that e- 
learning needs prepared effective pedagogies to cope with unexpected circumstances such as the pandemic of Covid-19.

\section{RECOMMENDATIONS}

Depending on the findings of the quantitative study drawn from the collected data, the following recommendations are suggested for implementing online learning and for further research.

- Interaction in online classes should be nurtured approximately with face-to-face instruction.

- To instil non-verbal cues to increase online understanding of students' affection.

- To motivate both professors and students to adapt e-learning as a new mode of delivery.

- To invest in the infrastructure to promote enough technical equipment support in terms of the materials used and the network.

- To invest in training professors and students in the manipulation of the platforms and applications of e-learning.

- To set a meaningful course design that targets students' needs.

- To encourage hybrid teaching/learning to vary the modes of delivery.

- To conduct more research on online learning using different approaches and research designs to come up with the strengths to develop and weaknesses to overcome.

\section{CONCLUSION}

To wrap up, the present study remains one of the attempts to measure the perceptions and satisfaction of Master students on the basis of their e-learning experience for one semester during the covid-19 pandemic in Morocco. It is also worth mentioning that elearning is still in its infancy in the Moroccan context in spite of the efforts made by stakeholders in higher education to make it a substitute for face-to-face instruction. Furthermore, it should not be ignored that distance education has been implemented as a preventive measure against the virus. Yet, decision makers have already started thinking of making it a successful project. Above all, measuring online learning with its degree of satisfaction aims at improving the quality of higher education by accentuating on learners' needs. For the same purpose, researchers in Morocco are called on to conduct more academic studies not only to manage the current situation of Covid-19 but to set unified principles for e-learning as a new pedagogy and a user-friendly medium to democratize education as well.

\section{REFERENCES}

Bielecki, W. T. (2002). Fundamentals for E-learning Systems. Retrieved October 20, 2020 from http://republika.pl/webmarketing/materialy/eLearning/e-learning_tekst.htm

Buzzetto-More, N., (2006). The E-Iearning and Business Education Paradigm: Enhancing Education, Assessment, Accountability. Proceedings of Mary Land Business Education Association Conference. Ocean City. MD.

Buzzetto-More, N. A., \& Alade, A. J. (2006). Best practices in e-assessment. Journal of Information Technology Education: Research, 5(1), 251-269.

Cohen, E. B. (1999). From ugly duckling to swan: Reconceptualizing information systems as a field of the discipline informing science. Journal of Computing and Information Technology, 7(3), 213-219. 
Hicks, S. (2004). How to measure the success of your e-learning program. Career Journal Europe.com. $\quad$ Retrieved October 4, 2020, from http://www.careerjournaleurope.com/hrcenter/astd/features/20010321-hicks.html

Hulin, C., Netemeyer, R., \& Cudeck, R. (2001). Can a reliability coefficient be too high?. Journal of Consumer Psychology, 10 (1/2), 55-58.

Imel, S. (2002). E-learning: Trends and issues alert. ERIC Clearinghouse on Adult, Career, and Vocational Education. Report Number 40.

Nicole A. Buzzetto-Bodendorf, F., Schertler, M., \& Cohen, E. (2005). Producing reusable web-based multimedia presentations. Interdisciplinary Journal of Knowledge and Learning Objects, 1, 127-142.

Nycz, M., \& Cohen, E. (2006). The basics for understanding e-learning. Principles of effective online teaching, 1-17.

Parker, M. (2003). Technology-enhanced e-learning: Perceptions of first year information systems students at the Cape Technikon. Proceedings Of The 2003 Annual Research Conference of the South African Institute of Computer Scientists and Information Technologists on Enablement through Technology (SAICSIT) 2003. Retrieved November 1, 2020, from http://delivery.acm.org/10.1145/960000/954049/pp.316-319 Parker.pdf?key $1=954049 \&$ key $2=0750103011 \&$ coll=GUIDE $\& d \mathrm{l}=$ GUIDE $\& C F I D=3381$ $310 \&$ CFTOKEN $=86548055$

Partridge, H. \& Edwards, S. (2005). Establishing the IT student's perspective to e-learning: Preliminary findings from a Queensland University of Technology case study. Issues in Informing Science and Information Technology, Vol. 2 pp. 297-312.

Razak, N. A., Yassin, A. A., \& Maasum, T. N. R. T. M. (2020). Formalizing Informal CALL in Learning English Language Skills. In Enhancements and Limitations to ICT-Based Informal Language Learning: Emerging Research and Opportunities (pp. 161-182). IGI Global.

\section{AUTHOR'S BIO}

Dr. Abdelmajid JAMIAI is a full time professor of Applied Linguistics at the Faculty of Languages, Arts and Human Sciences of Settat, Hassan First University, Morocco. Abdelmajid JAMIAI is interested in many fields such as online pedagogy, theories of elearning (Computer-Mediated Communication and Social Presence). His experience in teaching includes English for General Purposes (EGP), English for Specific Purposes (ESP), Theoretical Linguistics and Communication. Professor JAMIAI has also participated in national and international webinars on issues of transformational leadership and English language teaching (ELT). 